OPEN ACCESS

Edited by:

Dake Xu,

Northeastern University, China

Reviewed by:

Ru Jia,

Texas A\&M University, United States

Jose Maria Bastidas,

Centro Nacional De Investigaciones

Metalurgicas (CENIM), Spain

Chunguang Yang,

Institute of Metals Research (CAS),

China

*Correspondence:

Ke Chai

chaike888@sina.com

${ }^{t}$ These authors have contributed equally to this work

Specialty section:

This article was submitted to

Microbiological Chemistry and Geomicrobiology,

a section of the journal

Frontiers in Microbiology

Received: 08 June 2019

Accepted: 11 February 2020

Published: 03 March 2020

Citation:

Wu J, Zhang W, Chai K and Yu A

(2020) Corrosion Behavior of AISI

1045 Steel in Seawater

in the Presence of Flavobacterium sp.

Front. Microbiol. 11:303.

doi: 10.3389/fmicb.2020.00303

\section{Corrosion Behavior of AISI 1045 Steel in Seawater in the Presence of Flavobacterium sp.}

\author{
Jinyi Wu ${ }^{1,2+}$, Weixiong Zhang ${ }^{1+}$, Ke Chai ${ }^{1 *}$ and Aimin $\mathrm{Yu}^{2}$ \\ ${ }^{1}$ Key Laboratory of Tropical Biological Resources of Ministry of Education, School of Life and Pharmaceutical Sciences, \\ School of Materials Science and Engineering, Hainan University, Haikou, China, ${ }^{2}$ Department of Chemistry and \\ Biotechnology, Swinburne University of Technology, Melbourne, VIC, Australia
}

A systematic comparison study was carried out to investigate the effect of Flavobacterium sp. on AISI 1045 steel corrosion by weight loss, fluorescence microscopy (FM), surface analysis, cell count, pH measure, electrochemical impedance spectroscopy (EIS), and polarization curves. The impedances were considerably increased by Flavobacterium sp. between 1 and 7 day exposure and after 30 day exposure but considerably decreased by Flavobacterium sp. after 15 and 21 day exposure, which were supported by the $\mathrm{I}_{\text {corr }}$ results and the weight loss data. Furthermore, the biofilm was formed on the coupons. The $\mathrm{pH}$ values were considerably decreased by Flavobacterium sp. after 15 and 21 day exposure. The results proved that Flavobacterium sp. decreased the corrosion rates between 1 and 7 day exposure and after 30 day exposure and increased the corrosion rates between 15 and 21 day exposure, which could be ascribed to the protective biofilm and the secreted corrosive acid, respectively. In addition, Flavobacterium sp. considerably increased the pit numbers, the maximum pit depths, and the corresponding widths and considerably decreased the $E_{\text {pit }}$ values. Importantly, the coverage and the heterogeneity of the biofilm were positively correlated with the increases in the maximum pit depths and the corresponding widths and the decreases in the $E_{\text {pit }}$ values by Flavobacterium sp. The results demonstrated that Flavobacterium sp. increased the pitting corrosion, which could involve the heterogeneous biofilm cover.

Keywords: Flavobacterium sp., AISI 1045 steel, corrosion, seawater, biofilm

\section{INTRODUCTION}

Ocean is a continuous vast body of salt water that covers more than $70 \%$ of the surface of the earth. It is home to abundant biological, mineral, and energy resources. The ocean explorations and exploitations like the ocean investigation, the ocean transportation, and the offshore oil and gas industries are now proceeding rapidly (Bhandari et al., 2015). More and more marine facilities such as ports, bridges, offshore platforms, ships, and submarine pipelines have been built. Steels are the fundamental construction materials of these marine structures (Cook, 2005). However, seawater contains numerous microorganisms and a number of corrosive matters like oxygen, hydrion, chloridion, and so on (Page, 1975; Li X. et al., 2017; Jin et al., 2019). The steels exposed in 
seawater are prone to corrosion due to the reactions between the steels and the corrosive matters (Melchers and Jeffrey, 2008; Popoola et al., 2013). It is worth noting that microorganisms can colonize on the surface of metals and form biofilms and change the distributions of the corrosive matters in the environment of metals (Voordouw et al., 2016; Hu et al., 2019; Dong et al., 2020). Consequently, many microorganisms can lead to the corrosion of metals, i.e., microbiologically influenced corrosion (MIC). The steels exposed in seawater are especially susceptible to MIC.

Studies have revealed many microorganisms related to MIC. Sulfate reducing bacteria (SRB) constitute an important group of corrosive bacteria (Li et al., 2018). They induce corrosion through oxidizing hydrogen at the cathodes of galvanic corrosion cells or directly oxidizing ferrum with sulfate as terminal oxidant (Dou et al., 2018; Gu et al., 2019). Desulfovibrio vulgaris increased the corrosion rates and the pitting corrosion of C1010 carbon steel (Chen et al., 2015), two aluminum alloys (Liu et al., 2014), copper (Jayaraman et al., 1999), and seven stainless steels (Ringas and Robinson, 1988). The mixture of Desulfovibrio gabonensis and Desulfovibrio capillatus accelerated the corrosion of SAE-1018 carbon steel (Castaneda and Benetton, 2008). Desulfotomaculum nigrificans considerably promoted both the general corrosion and localized corrosion of Q235 carbon steel (Liu et al., 2019). More importantly, SRB have been reported to be responsible for the corrosion deterioration of oil, power generation and marine industries, cooling water systems, etc. (Ilhan-Sungur and Çotuk, 2010; Guan et al., 2013; Li Y. et al., 2016). Pseudomonas is the most prevalent bacterial genus in marine environment (Yuan et al., 2008). So far, it is well known that some species of Pseudomonas are corrosive. Pseudomonas sp. enhanced the corrosion rate and the pitting corrosion of AISI 1045 steel and further reduced the tensile strength of the steel (Wu et al., 2012). Pseudomonas aeruginosa induced the corrosion of 2205 duplex stainless steel (Xu et al., 2017; Zhao et al., 2017), 2304 duplex stainless steel (Zhou et al., 2018), the nickel-free high nitrogen stainless steel (Li H. et al., 2016), and S32654 super austenitic stainless steel (Li H. et al., 2017). The presence of Pseudomonas fluorescens promoted the electrochemical reaction on singlephase $\mathrm{Cu}-\mathrm{Sn}$ modern bronze, and led to pitting corrosion underneath the biofilm (Ghiara et al., 2018). Iron oxidizing bacteria (IOB) are another group of corrosive bacteria, which increase corrosion reaction by oxidizing ferrous ion to ferric ion (Chen et al., 2019). Sphaerotilus sp. strongly accelerated the pitting corrosion of AISI 1020 steel (Starosvetsky et al., 2001). Acidithiobacillus ferrooxidans in seawater accelerated the corrosion rate of C1010 steel and caused pitting corrosion (Wang H. et al., 2014). Although most studies showed that microorganisms promoted corrosion, some reports revealed the different results. Hernandez et al. (1994) reported that Pseudomonas sp. S9 could inhibit the corrosion of mild steel. Additionally, Desulfovibrio sp. inhibited the corrosion of SAE 1018 carbon steel for some time, but it became quite corrosive to the steel at longer times (Pérez et al., 2007).

Flavobacterium is ubiquitous in ocean (Abell and Bowman, 2005; Pesciaroli et al., 2012). Our previous work showed that when the exposure time was 365 days, the average corrosion rate of AISI 1045 steel exposed in natural seawater was about 2.1 times that of the steel exposed in sterile seawater and the content of Flavobacterium sp. in the corrosion products was much higher than those of the other bacteria in the corrosion products (Xiao, 2011), suggesting that Flavobacterium sp. might increase the steel corrosion greatly. However, very little is known about the effect of Flavobacterium sp. on the corrosion of metals. Moreover, AISI 1045 steel is widely used in marine structures for its low cost and excellent mechanical properties such as outstanding hardness and toughness, etc. (OrjuelaG et al., 2014). In this work, we carried out a systematic comparison of the corrosion of AISI 1045 steel exposed in sterile seawater and Flavobacterium sp. inoculated seawater by weight loss, fluorescence microscopy (FM), surface analysis, cell count, $\mathrm{pH}$ measure, electrochemical impedance spectroscopy (EIS), and polarization curves.

\section{EXPERIMENTS}

\section{Material}

AISI 1045 steel purchased from Qiqihar Hongshun Heavy Industry Group Co. Ltd. (China) has the following composition (wt.\%): $98.582 \mathrm{Fe}, 0.499 \mathrm{C}, 0.596 \mathrm{Mn}, 0.230 \mathrm{Si}, 0.028 \mathrm{~S}, 0.012$ P, $0.006 \mathrm{Ni}, 0.020 \mathrm{Cr}, 0.001 \mathrm{Mo}, 0.001 \mathrm{Nb}, 0.014 \mathrm{Cu}, 0.003 \mathrm{~W}$, $0.003 \mathrm{Al}, 0.004 \mathrm{~V}, 0.001 \mathrm{Ti}$. The carbon steel coupons with the dimensions of $50 \times 25 \times 3 \mathrm{~mm}, 15 \times 10 \times 3 \mathrm{~mm}$, and $\Phi 10 \times 3 \mathrm{~mm}$ were used in weight loss, surface analysis, and electrochemical measurement, respectively. The coupons were sequentially abraded with 120, 400, 800, 1200, and 1500 grit $\mathrm{SiC}$ paper to obtain smooth surfaces. Then, they were degreased with acetone, rinsed with distilled water and ethanol, dried in air aseptically. Subsequently, all the coupons were kept in a desiccator before the measurement.

\section{Culture of Flavobacterium sp.}

The Flavobacterium sp. used in this study was separated from the corrosion products of AISI 1045 steel exposed in nature seawater for 12 months. Flavobacterium sp. was cultured at $26^{\circ} \mathrm{C}$ for 2 days in $2216 \mathrm{E}$ medium, which contained $1 \mathrm{~g}$ yeast extract, $5 \mathrm{~g}$ peptone, and $1000 \mathrm{~mL}$ natural seawater. The $\mathrm{pH}$ of medium was adjusted to 7.8 with $1 \mathrm{M} \mathrm{NaOH}$ solution and the medium was sterilized in an autoclave at $121^{\circ} \mathrm{C}$ for $20 \mathrm{~min}$ before use; $20 \mathrm{~mL}$ of the bacterial culture solution was mixed with $2000 \mathrm{~mL}$ of sterile seawater. The mixture was cultured at $26^{\circ} \mathrm{C}$ for $24 \mathrm{~h}$. The prepared coupons were exposed in Flavobacterium sp. inoculated seawater and sterile seawater at $26^{\circ} \mathrm{C}$. The $\mathrm{pH}$ values of sterile seawater and Flavobacterium sp. inoculated seawater were measured by a $\mathrm{pH}$ meter after $3,7,15,21$, and 30 day exposure.

\section{Weight Loss}

Clarke' s solution (antimonous oxide, $20 \mathrm{~g}$; stannous chloride, $50 \mathrm{~g} ; 36 \%$ hydrochloric acid, $1 \mathrm{~L}$ ) was used to clean the coupon, after which the coupon was rinsed with distilled water and analytically pure ethanol. The weight loss was obtained after the coupon had been dried. The average corrosion rate was calculated using the following Eq. (1).

$$
V(m m / a)=(K \times W) /(A \times T \times D)
$$


where $V$ is the average corrosion rate, $m m / a ; W$ is the weight loss of the coupon, $\mathrm{g} ; \mathrm{K}$ is $3.65 \times 10^{3} ; A$ is the total area of the coupon, $\mathrm{cm}^{2} ; T$ is the exposure time, day; and $D$ is the density of the coupon, $\mathrm{g} / \mathrm{cm}^{3}$.

\section{Fluorescence Microscopy}

Fluorescence microscopy was applied to observe the changes of the Flavobacterium sp. biofilm. After exposure, the coupon was rinsed with phosphate buffer saline (PBS), and stained with acridine orange (AO) for $5 \mathrm{~min}$. The images were captured under a fluorescence microscope (Mshot MF41). The biofilm coverages were extracted from 20 random different images of the coupon using the software V9.0. The heterogeneity of the biofilm of the coupon was calculated using the following Eq. (2) (Wang Z. et al., 2014).

$$
H=\sqrt{\frac{\sum_{i=1}^{N}\left(S_{i}-S\right)^{2}}{N-1}}
$$

where $H$ is the heterogeneity of the biofilm of the coupon; $N$ is the quantity of the random different images of the coupon; $S_{i}$ is the biofilm coverage of one image, $\% ; S$ is the average biofilm coverage of the images, i.e., the biofilm coverage of the coupon, $\%$.

\section{Surface Analysis}

The surfaces of the coupons were observed by scanning electron microscopy (SEM) (Hitachi S-4800) after 7, 15, and 30 day exposure. The coupons were treated according to the previously reported method (Yuan et al., 2008) with a minimum revision. Briefly, the coupons were rinsed with PBS solution twice and fixed in a 2.5 vol\% PBS solution of glutaraldehyde for $8 \mathrm{~h}$ at $4^{\circ} \mathrm{C}$, and then they were washed twice with deionized water to remove glutaraldehyde and dehydrated with 25, 50, 75, 90, 100 vol\% stepwise ethanol for $10 \mathrm{~min}$ each. At last, they were dried in an airtight desiccator. To observe the corrosion morphology on the underlying metal surfaces, the biofilm and the corrosion products of the coupons were removed after 7, 15, and 30 day exposure, according to the above method in weight loss. The maximum pit depths and the corresponding widths were measured by 3D laser scanning confocal microscopy (Keyence VK-X250K).

\section{Cell Count}

The living cells in Flavobacterium sp. inoculated seawater were counted after $3,7,15,21$, and 30 day exposure; $10 \mathrm{~mL}$ of Flavobacterium sp. inoculated seawater were serially diluted with sterile seawater; $100 \mu \mathrm{L}$ solutions of the appropriate dilutions were inoculated on solid medium and incubated at $26^{\circ} \mathrm{C}$ for $48 \mathrm{~h}$. Bacterial numbers were determined by the plate count.

\section{Electrochemical Analysis}

A PARSTAT 2273 electrochemical workstation (Princeton Applied Research) with a three-electrode system was used for the measurements of EIS and polarization curves. The saturated calomel electrode (SCE) and the platinum electrode were employed as the reference electrode and the counter electrode, respectively. The working electrode was a coupon encapsulated in epoxy with an end surface exposed and the other end surface connected to a wire. The test solutions were sterile seawater and Flavobacterium sp. inoculated seawater, respectively. The test temperature was kept at $26^{\circ} \mathrm{C}$. The EIS was measured at the open circuit potential (OCP) with an amplitude sinusoidal signal of $10 \mathrm{mV}$ and the frequency range of $0.005-100,000 \mathrm{~Hz}$. The equivalent electrical circuits (EECs) were determined using evaluator software (Zsimpwin). The sweep of polarization curves was performed with a voltage range from -1.4 to $0.4 \mathrm{~V}$ vs. SCE at a scan rate of $2.0 \mathrm{mV} / \mathrm{s}$ to determine the corrosion potential $\left(\mathrm{E}_{\mathrm{corr}}\right)$ and the corrosion current density $\left(\mathrm{I}_{\text {corr }}\right)$.

\section{RESULTS}

\section{Average Corrosion Rates}

Figure 1 presents the average corrosion rates of AISI 1045 steel after $3,7,15,21$, and 30 day exposure in sterile seawater and Flavobacterium sp. inoculated seawater. The average corrosion rate in sterile seawater slightly decreased from 3 to 7 day exposure and considerably decreased from 7 to 15 day exposure. At last, it slightly decreased from 15 to 21 day exposure and 21 to 30 day exposure. The average corrosion rate in Flavobacterium sp. inoculated seawater decreased from 3 to 7 day exposure, considerably increased from 7 to 15 day exposure and slightly decreased from 15 to 21 day exposure. Subsequently, it considerably decreased from 21 to 30 day exposure and reached a slightly lower level than that after 30 day exposure in sterile seawater. The average corrosion rates in Flavobacterium sp. inoculated seawater were considerably lower than the corresponding ones in sterile seawater after 3 and 7 day exposure. However, the average corrosion rates in Flavobacterium sp. inoculated seawater were considerably higher

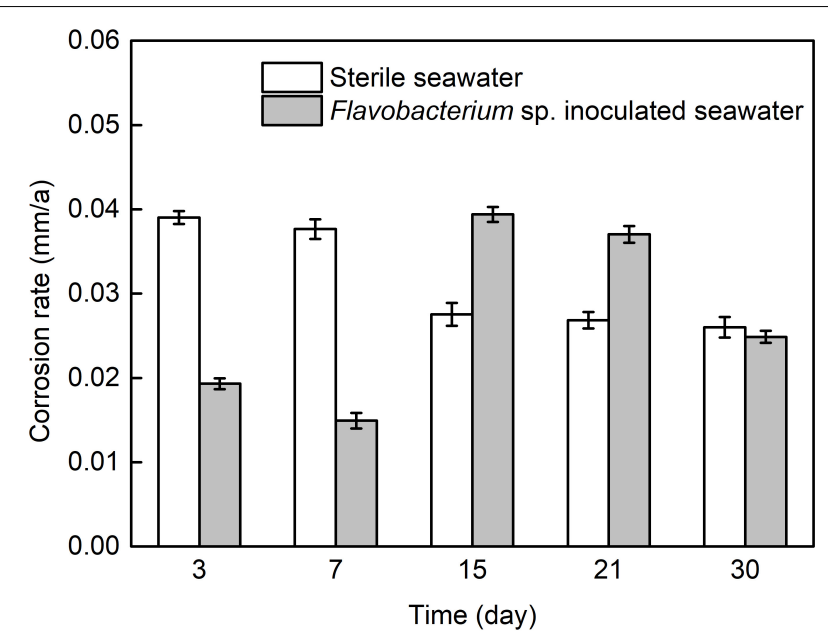

FIGURE 1 | The average corrosion rates of AISI 1045 steel exposed in sterile seawater and Flavobacterium sp. inoculated seawater for the different times. The error bars represent the standard deviations of the six tests. 
than the corresponding ones in sterile seawater after 15 and 21 day exposure.

\section{Fluorescence Microscopy}

The Flavobacterium sp. biofilm on the coupons were presented by FM after 3, 7, 15, 21, and 30 day exposure (Figures 2A-E). Sparse Flavobacterium sp. cells attached to the coupon surface dispersedly and only two tiny cell clusters were distinguished after 3 day exposure (Figure 2A). After 7 day exposure, some bacterial cells clustered on the coupon surface and sparse ones distributed around (Figure 2B). With the exposure time increasing, more Flavobacterium sp. cells accumulated to form bigger and denser colonies, besides a small number of cells still distributed around (Figures 2C-E). Especially, the biggest and densest cell colony was detected after 30 day exposure (Figure 2E). Accordingly, the coverage and the heterogeneity of the biofilm increased with exposure time.
Meanwhile, they considerably increased from 7 to 15 day exposure (Figures 2F,G).

\section{Surface Analysis}

The surface morphology of the coupons after 7, 15, and 30 day exposure showed that the corrosion products film covered the coupons exposed in sterile seawater (Figures 3A-C) and the biofilm/the corrosion products film covered the coupons exposed in Flavobacterium sp. inoculated seawater (Figures 3DG). In sterile seawater, the corrosion scales were lumpy and many corrosion tubercles formed (Figures $\mathbf{3 A}-\mathbf{C}$ ). The amount of the corrosion products increased with exposure time (Figures 3A-C). In Flavobacterium sp. inoculated seawater, some Flavobacterium sp. cells adhered with the corrosion products to the coupon surface after 7 day exposure (Figure 3D). More and denser cells accumulated in the corrosion products on the coupons after 15 day exposure (Figure 3E). The quantity and
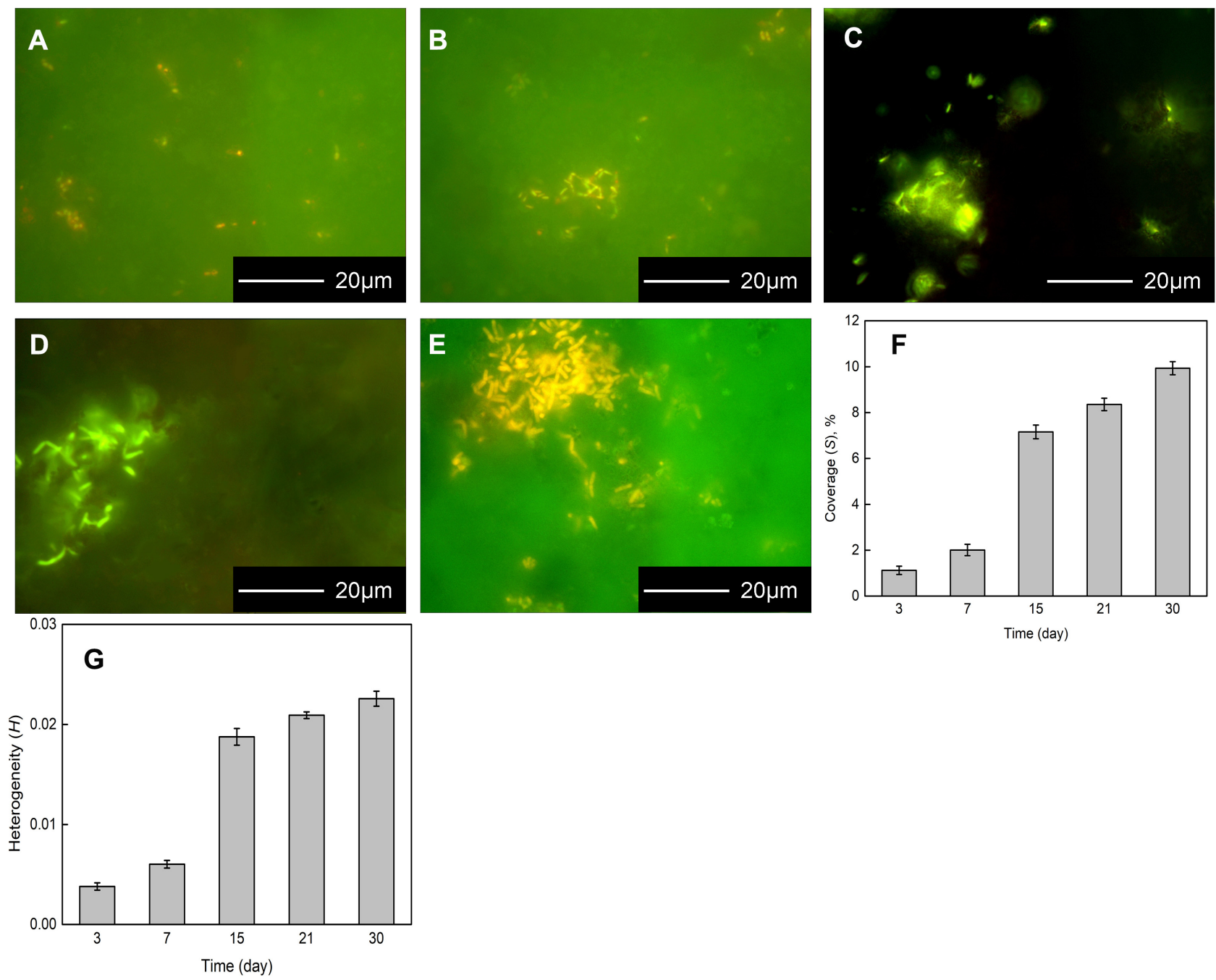

FIGURE 2 | Fluorescence images of bacterial cells attaching to the coupons exposed in Flavobacterium sp. inoculated seawater for 3 (A), 7 (B), 15 (C), 21 (D), and 30 days $\mathbf{( E )}$ and the coverages of the biofilm $\mathbf{( F )}$ and the heterogeneities of the biofilm (G) after 3, 7, 15, 21, and 30 day exposure. The error bars represent the standard deviations of the six tests. 

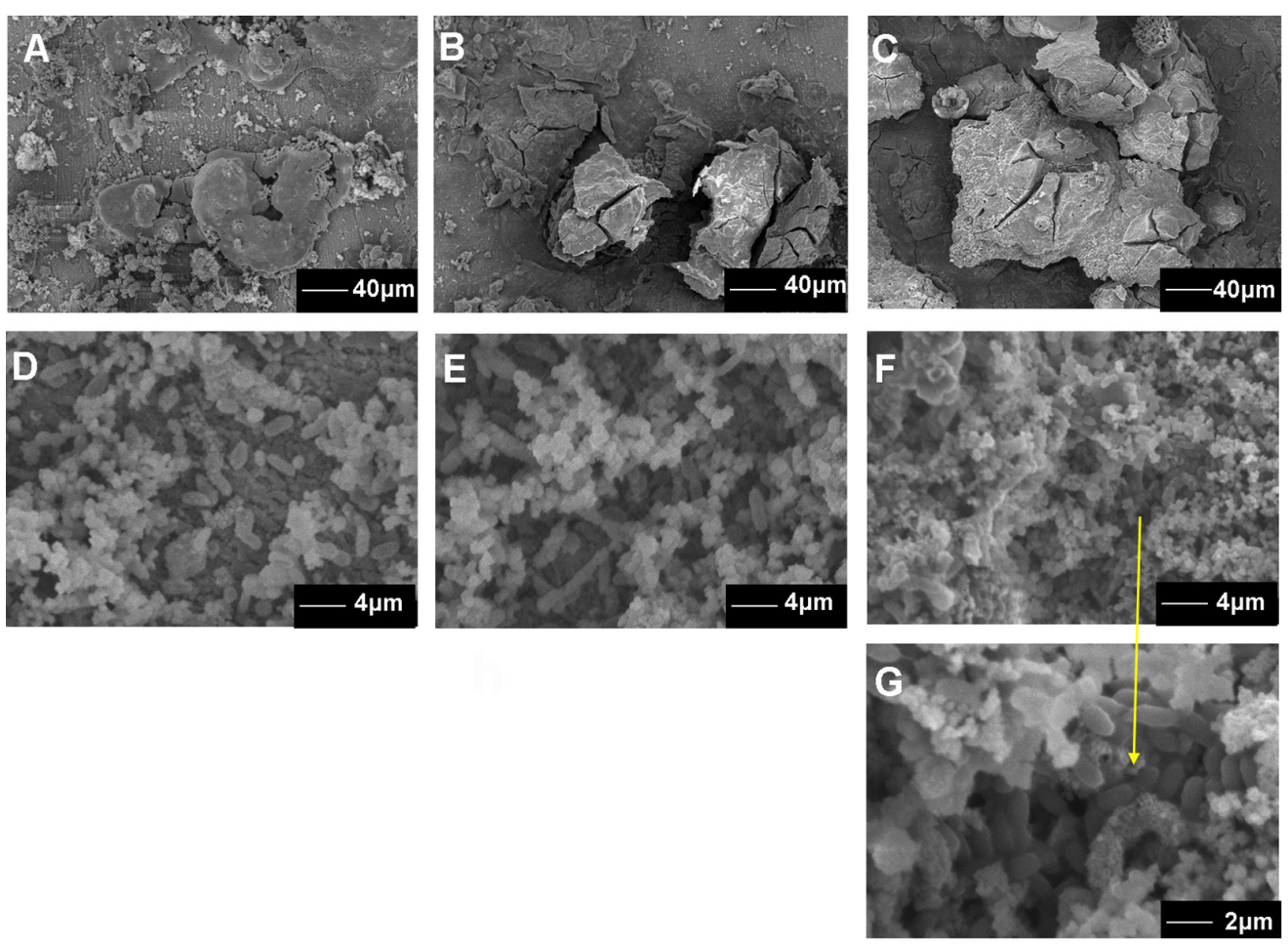

FIGURE 3 | The SEM images of the surface morphology of the AISI 1045 steel coupons after 7 (A), 15 (B), and 30 day exposure in sterile seawater (C) and 7 (D), 15 (E), and 30 day exposure in Flavobacterium sp. inoculated seawater (F,G).

the density of cells reached the maximum after 30 day exposure (Figures 3F,G).

For the coupons exposed in sterile seawater for 7,15 , and 30 days, the pit number increased with the exposure time

(Figures 4A-C). For the coupons exposed in Flavobacterium sp. inoculated seawater for 7,15 , and 30 days, the pit number also increased with the exposure time and the pit numbers were considerably higher than the corresponding ones of the coupons exposed in sterile seawater (Figures $\mathbf{4 A - F}$ ). The maximum pit depths were 5.39, 10.27, and $11.25 \mu \mathrm{m}$ with the widths of
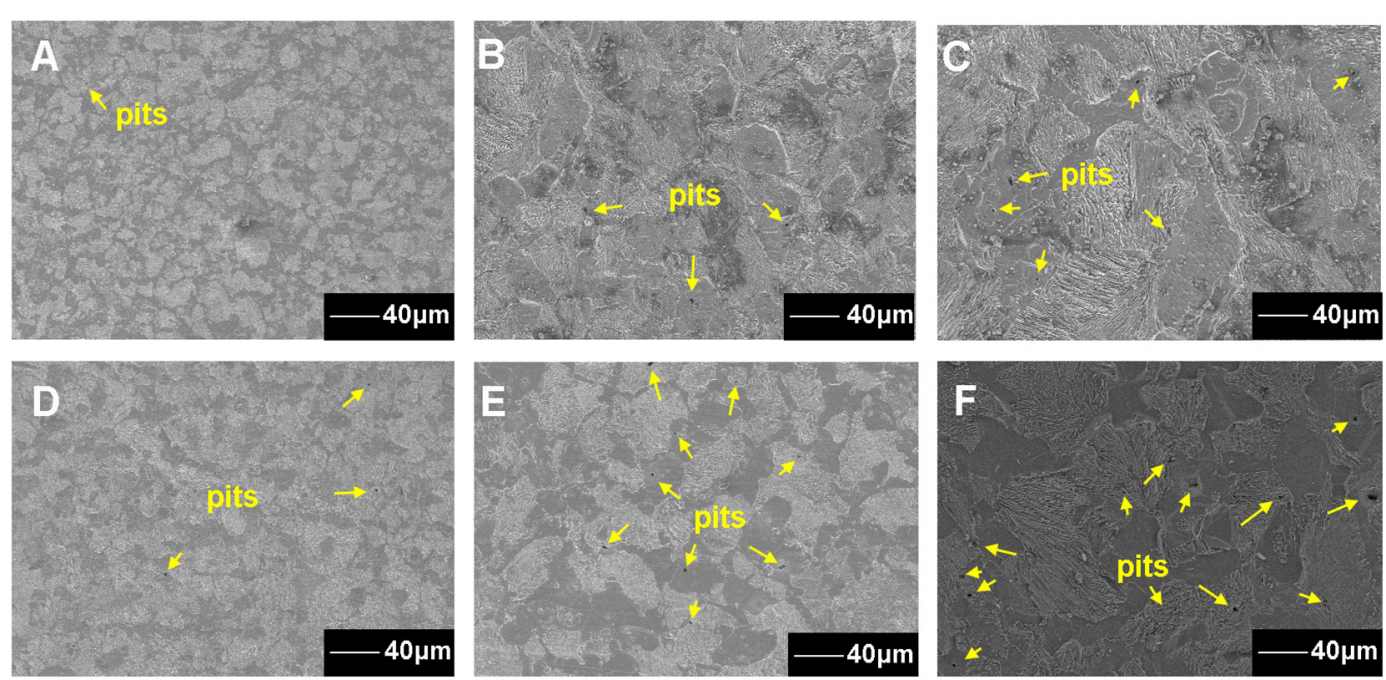

FIGURE 4 | The SEM images of the metal surface corrosion morphology after the removal of the corrosion products and the biofilm from the coupons after 7 (A), 15 (B), and 30 day exposure in sterile seawater (C) and 7 (D), 15 (E), and 30 day exposure in Flavobacterium sp. inoculated seawater (F). 

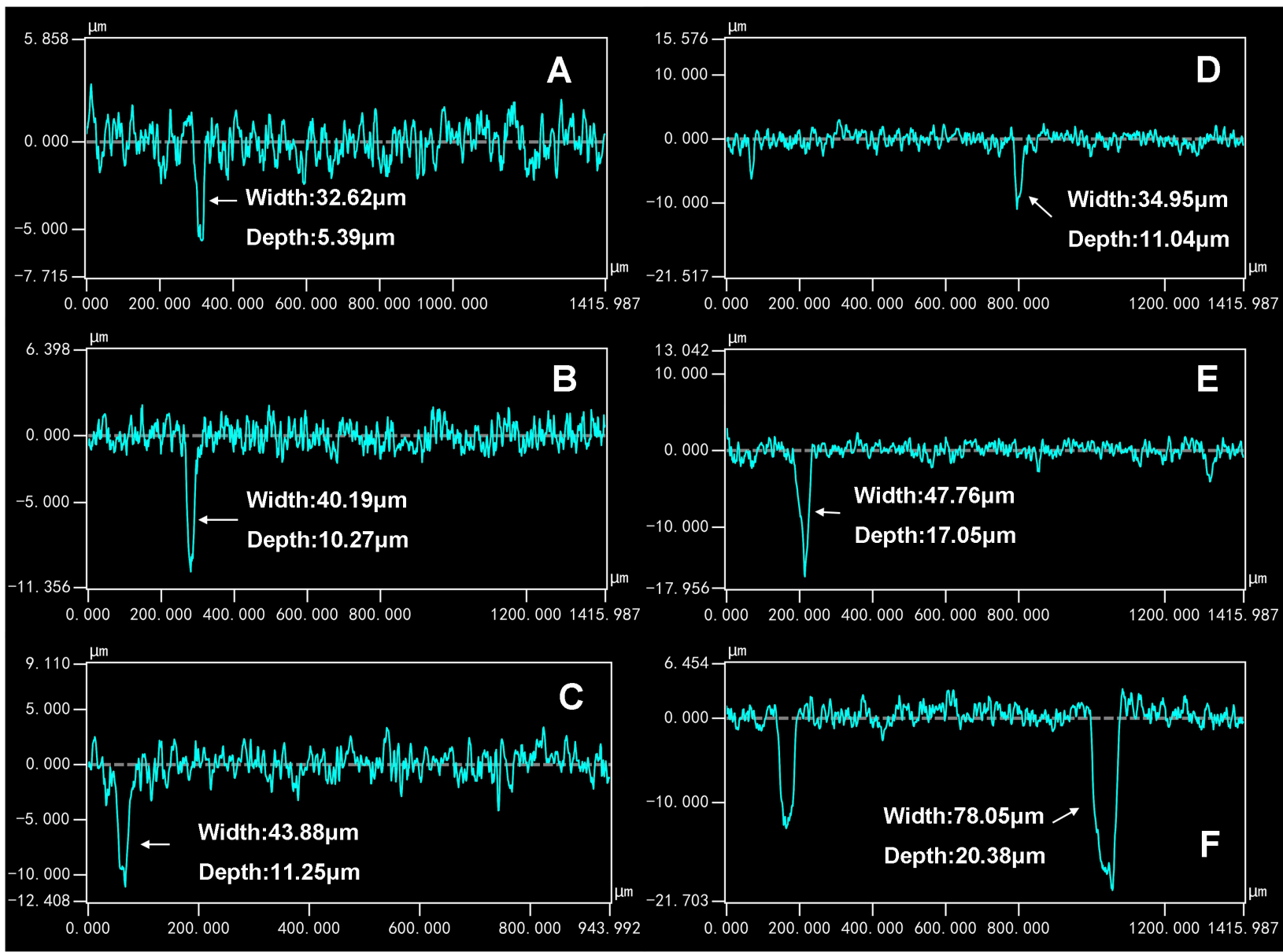

FIGURE 5 | The maximum pit depths and the corresponding widths of the coupons after 7 (A), 15 (B), and 30 day exposure in sterile seawater (C) and 7 (D), 15 (E), and 30 day exposure in Flavobacterium sp. inoculated seawater (F).

32.62, 40.19, and $43.88 \mu \mathrm{m}$ after 7,15 , and 30 day exposure in sterile seawater, respectively (Figures $\mathbf{5 A - C}$ ). After 7, 15, and 30 day exposure in Flavobacterium sp. inoculated seawater, the maximum pit depths were $11.04,17.05$, and $20.38 \mu \mathrm{m}$, increasing by $5.65,6.78$, and $9.13 \mu \mathrm{m}$ against the corresponding ones in sterile seawater, respectively (Figures $\mathbf{5 A - F}$ ). The corresponding widths were $34.95,47.76$, and $78.05 \mu \mathrm{m}$, growing by $2.33,7.57$, and $34.17 \mu \mathrm{m}$ against the corresponding ones in sterile seawater, respectively (Figures 5A-F).

\section{Cell Count}

Figure 6 shows that the cell number in Flavobacterium sp. inoculated seawater changed with exposure time. It slightly increased from 3 to 7 day exposure and considerably increased from 7 to 15 day exposure. It then considerably decreased from 15 to 21 day exposure and 21 to 30 day exposure.

\section{pH Analysis}

Figure 7 presents the $\mathrm{pH}$ values in the two seawaters after 3, 7, 15,21 , and 30 day exposure. The $\mathrm{pH}$ values in sterile seawater stayed at the similar levels around 8.0 after 3, 7, 15, 21, and
30 day exposure. In Flavobacterium sp. inoculated seawater, the $\mathrm{pH}$ values were only slightly lower than the corresponding ones in sterile seawater after 3, 7, and 30 day exposure and considerably lower than the corresponding ones in sterile seawater after 15 and 21 day exposure. In addition, the $\mathrm{pH}$ value in Flavobacterium sp. inoculated seawater slightly decreased from 3 to 7 day exposure and considerably decreased from 7 to 15 day exposure. Then it considerably increased from 15 to 21 day exposure and 21 to 30 day exposure.

\section{EIS Analysis}

Electrochemical measurement is an efficient and fast method characterizing the transient electrochemical reactions occurring among metal surface, corrosion products, and biofilm (Mansfeld and Little, 1991). The EIS data acquired for the coupons exposed in the two seawaters are shown in Figure 8, in which the inset plots at high-frequency were included. As shown in the Nyquist plots (Figures $\mathbf{8 A}, \mathbf{B}$ ), there were two time constants present in the impedance spectra in the two seawaters. They consisted of an impedance loop at high-frequency and an impedance loop at low-frequency. In sterile seawater, the 


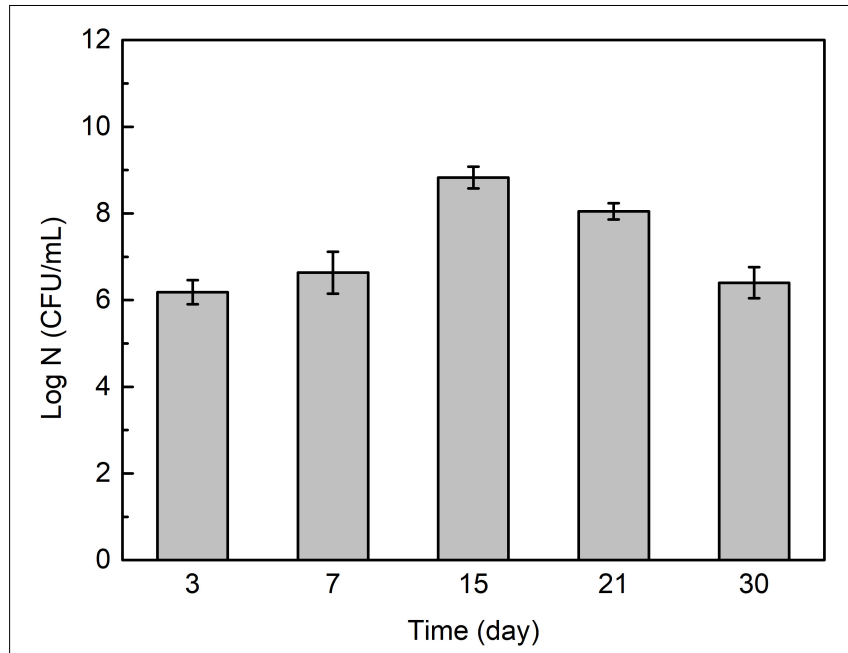

FIGURE 6 | The cell numbers in Flavobacterium sp. inoculated seawater after the different time exposure. The error bars represent the standard deviations of the six tests.

diameter of impedance loop at low-frequency slightly increased with exposure time between 1 and 7 day exposure, considerably increased from 7 to 15 day exposure and slightly increased from 15 to 21 day exposure and 21 to 30 day exposure (Figure 8A). In Flavobacterium sp. inoculated seawater, the diameter of impedance loop at low-frequency increased with exposure time between 1 and 7 day exposure (Figure 8B). Then it considerably decreased from 7 to 15 day exposure and reached the minimum (Figure 8B). Hereafter, it considerably increased from 15 to 21 day exposure and 21 to 30 day exposure (Figure 8B). Importantly, the diameters of impedance loops at low-frequency were considerably greater in Flavobacterium sp. inoculated seawater than in sterile seawater after 1, 3,

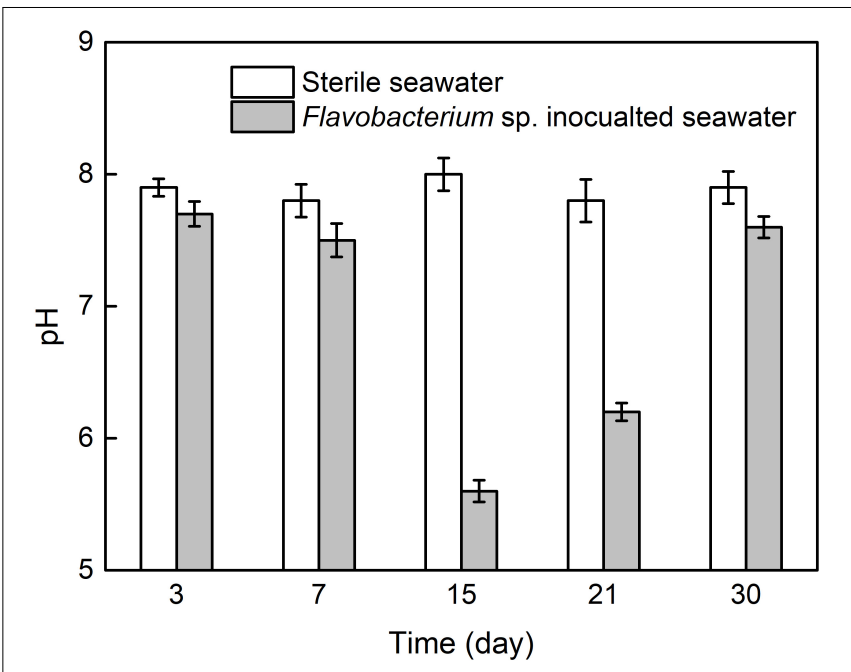

FIGURE 7 | The pH values in sterile seawater and Flavobacterium sp. inoculated seawater after the different time exposure. The error bars represent the standard deviations of the six tests.

5, 7, and 30 day exposure, respectively (Figures $\mathbf{8 A}, \mathbf{B}$ ), but considerably smaller in Flavobacterium sp. inoculated seawater than in sterile seawater after 15 and 21 day exposure, respectively (Figures 8A,B). The results were consistent with the results of the average corrosion rates.

The EIS data were simulated theoretically using the EEC that had two time constants as shown in Figure 9. The goodness of the fitting was evaluated by the chi-squared error $\left(\chi^{2}\right)$ between the experimental data and the fitting results. The error in the fitting was in the order of $10^{-4}$ in all cases (Table 1), which indicated that the EEC could be reliably used to fit the EIS data (Liu J.C. et al., 2015). The SEM observation revealed that the
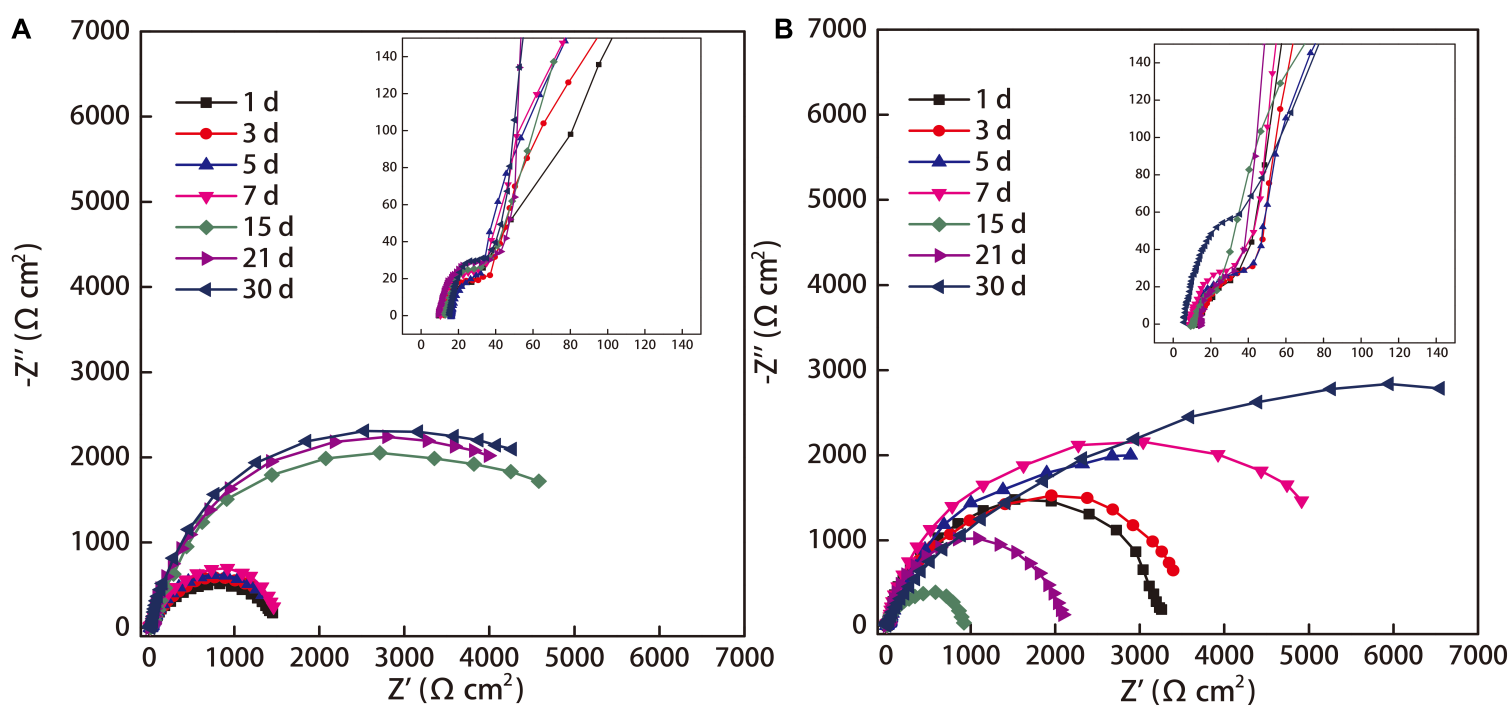

FIGURE 8 | Nyquist plots of the coupons exposed in sterile seawater (A) and Flavobacterium sp. inoculated seawater (B). 


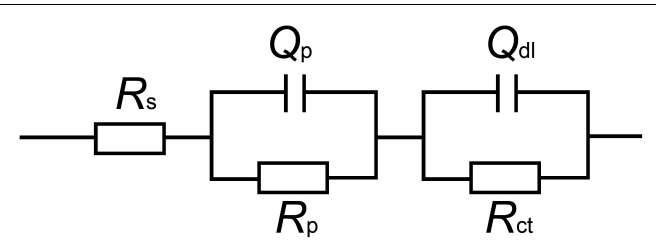

FIGURE 9 | Equivalent electrical circuit used to fit the EIS data: model of $R(Q R)(Q R)$ for the coupons exposed in sterile seawater and Flavobacterium $\mathrm{sp}$. inoculated seawater. $R_{s}$ : the solution resistance, $Q_{p}$ : the constant phase element (CPE) of the corrosion products film in sterile seawater or the CPE of the biofilm/the corrosion products film in Flavobacterium sp. inoculated seawater, $R_{p}$ : the resistance of the corrosion products film in sterile seawater or the resistance of the biofilm/the corrosion products film in Flavobacterium sp. inoculated seawater, $Q_{d \|}$ : the constant phase element (CPE) of the electrical double layer, $\mathrm{R}_{\mathrm{ct}}$ : the charge transfer resistance.

corrosion products film covered the coupons exposed in sterile seawater and the biofilm/the corrosion products film covered the coupons exposed in Flavobacterium sp. inoculated seawater. For the biofilm/the corrosion products film, Flavobacterium sp. cells adhered with the corrosion products to the coupon surface, indicating that the contributions of the biofilm and the corrosion products film to the EEC were indistinguishable. So the $\mathrm{R}(\mathrm{QR})(\mathrm{QR})$ model was fit for the coupons exposed in sterile seawater and Flavobacterium sp. inoculated seawater $(\mathrm{Qu}$ et al., 2015), in which $R_{s}, Q_{p}, R_{p}, Q_{d l}$, and $R_{c t}$, respectively, stood for the solution resistance, the constant phase element (CPE) of the corrosion products film in sterile seawater or the CPE of the biofilm/the corrosion products film in Flavobacterium sp. inoculated seawater, the resistance of the corrosion products film in sterile seawater or the resistance of the biofilm/the corrosion products film in Flavobacterium sp. inoculated seawater, the CPE of the electrical double layer, and the charge transfer resistance. The fitted electrochemical parameters are listed in Table 1. The $R_{p}$ value in sterile seawater increased from 1 to 30 day exposure.
The $\mathrm{R}_{\mathrm{ct}}$ value in sterile seawater slightly increased with exposure time between 1 and 7 day exposure, considerably increased from 7 to 15 day exposure, slightly increased from 15 to 21 day exposure and 21 to 30 day exposure. The $R_{p}$ and the $R_{c t}$ values in Flavobacterium sp. inoculated seawater increased with exposure time between 1 and 7 day exposure, considerably decreased from 7 to 15 day exposure and considerably increased from 15 to 21 day exposure and 21 to 30 day exposure. The $R_{p}$ and the $R_{c t}$ values in Flavobacterium sp. inoculated seawater were considerably higher than the corresponding ones in sterile seawater after $1,3,5,7$, and 30 day exposure. Nevertheless, the $R_{p}$ and the $R_{c t}$ values in Flavobacterium sp. inoculated seawater were considerably lower than the corresponding ones in sterile seawater after 15 and 21 day exposure. The results were in accord with the average corrosion rate results and the Nyquist data.

\section{Polarization Curves}

Figure 10 shows the Tafel polarization curves of the coupons exposed in sterile seawater and Flavobacterium sp. inoculated seawater. Tafel polarization parameters such as the corrosion potential $\left(\mathrm{E}_{\mathrm{corr}}\right)$, the anodic and cathodic Tafel slops $\left(\mathrm{b}_{\mathrm{a}}\right.$ and $\left.\mathrm{b}_{\mathrm{c}}\right)$, the corrosion current density $\left(\mathrm{I}_{\text {corr }}\right)$, and the pitting potential $\left(\mathrm{E}_{\mathrm{pit}}\right)$ extracted from the Tafel polarization curves are listed in Table 2. In sterile seawater, the corrosion current density $\left(\mathrm{I}_{\text {corr }}\right)$ values stayed at the higher levels between 1 and 7 day exposure. Then the $\mathrm{I}_{\text {corr }}$ value considerably decreased from 7 to 15 day exposure and slightly decreased from 15 to 21 day exposure and 21 to 30 day exposure. In Flavobacterium sp. inoculated seawater, the $\mathrm{I}_{\text {corr }}$ value decreased with exposure time between 1 and 7 day exposure, considerably increased from 7 to 15 day exposure and considerably decreased from 15 to 21 day exposure and 21 to 30 day exposure. The $\mathrm{I}_{\text {corr }}$ values were considerably higher in sterile seawater than in Flavobacterium sp. inoculated seawater after 1, 3, 5, 7, and 30 day exposure, respectively. However, the $\mathrm{I}_{\text {corr }}$ values were considerably lower in sterile seawater than in Flavobacterium sp. inoculated seawater

TABLE 1 | Fitted parameters of EIS after the different time exposure in sterile seawater and Flavobacterium sp. inoculated seawater.

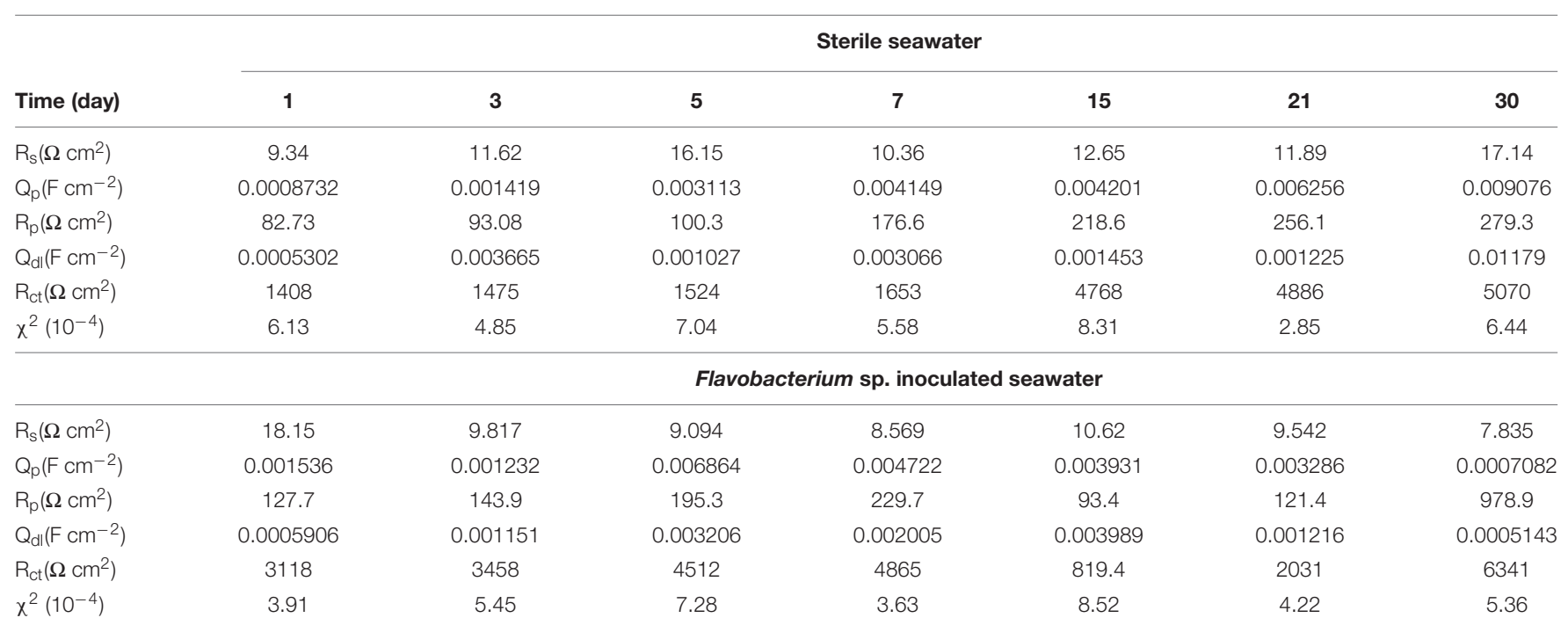



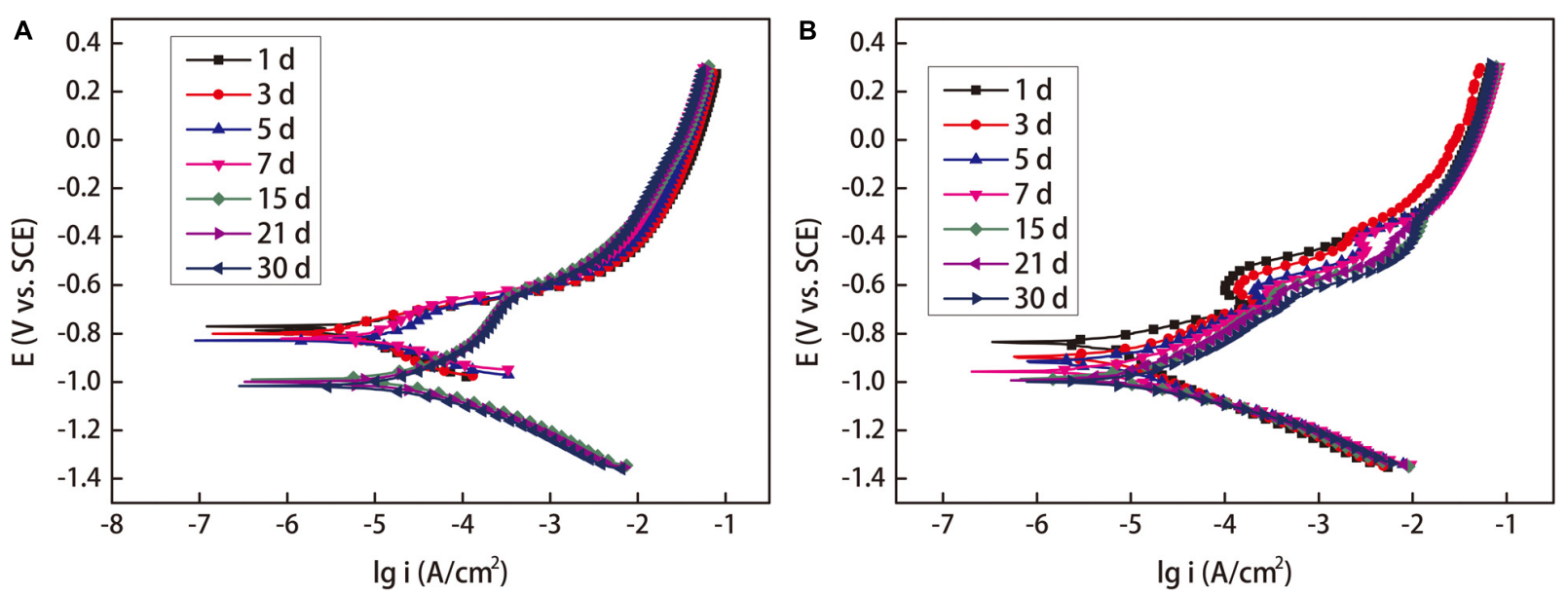

FIGURE 10 | Tafel polarization curves of the coupons exposed in sterile seawater (A) and Flavobacterium sp. inoculated seawater (B) for the different times.

TABLE 2 | Parameters of Tafel polarization curves of the coupons exposed in sterile seawater and Flavobacterium sp. inoculated seawater for the different times.

\begin{tabular}{|c|c|c|c|c|c|}
\hline \multirow[b]{2}{*}{ Time (day) } & \multicolumn{5}{|c|}{ Sterile seawater } \\
\hline & $I_{\text {corr }}\left(\mu \mathrm{A} / \mathrm{cm}^{2}\right)$ & $E_{\text {corr }}(m V$ vs. SCE) & $b_{a}(m V / d e c)$ & $b_{c}(m V / d e c)$ & $E_{\text {pit }}$ (mV vs. SCE) \\
\hline 3 & 6.67 & -800 & 63 & -168 & -352 \\
\hline 5 & 7.05 & -827 & 253 & -120 & -372 \\
\hline 7 & 5.55 & -819 & 109 & -126 & -381 \\
\hline \multirow[t]{2}{*}{30} & 1.86 & -1016 & 153 & -116 & -446 \\
\hline & \multicolumn{5}{|c|}{ Flavobacterium sp. inoculated seawater } \\
\hline 1 & 3.21 & -834 & 92 & -148 & -312 \\
\hline 3 & 2.92 & -895 & 188 & -132 & -381 \\
\hline 21 & 4.01 & -993 & 211 & -153 & -623 \\
\hline 30 & 1.25 & -998 & 128 & -87 & -650 \\
\hline
\end{tabular}

after 15 and 21 day exposure, respectively. The results were in agreement with the results of the average corrosion rates and the EIS. The pitting potential $\left(\mathrm{E}_{\mathrm{pit}}\right)$ values decreased over exposure time in the two seawaters. In addition, the $\mathrm{E}_{\text {pit }}$ values in Flavobacterium sp. inoculated seawater were considerably lower than the corresponding ones in sterile seawater between 1 and 30 day exposure. The results supported the surface analysis results.

\section{DISCUSSION}

The EIS is the powerful tool for detecting the different electrochemical processes at the interfaces between the electrodes and the electrolytes. The impedance loop diameter in the Nyquist plot, the $R_{c t}$ value, and the $R_{p}$ value are the key indicators of a corrosion rate (Liu H. et al., 2015, Batmanghelich et al., 2017; Liu et al., 2017; Song et al., 2018). The higher values of the three data represent the higher electrical resistances at the interfaces between the coupons and the electrolytes and the lower corrosion rates. In this study, the EIS data showed two time constants in the two seawaters. The time constant at high frequency corresponded to the corrosion products film formed on the coupon exposed in sterile seawater or the biofilm/the corrosion products film formed on the coupon exposed in Flavobacterium sp. inoculated seawater. The time constant at low frequency represented the charge transfer process in the electrical double layer, which was established at the steel and seawater interface. Many authors had found similar results. The impedance spectra of carbon steel Q235 in soil-extract solution with Desulfovibrio desulfuricans revealed that the time constants in the high frequency region were due to the forming of the corrosion products and the biofilm, 
and the time constant in the low frequency region was due to the electrical double layer (Xu et al., 2012). The EIS of 2205 duplex stainless steel corrosion by $P$. aeruginosa showed that the time constant at the higher frequency was most likely due to the biofilm/the corrosion products film, while the time constant at the lower frequency could be attributed to the electrical double layer (Xu et al., 2017). The EIS of 5052 aluminum alloy had two time constants: the one at high-frequency was associated with the formation of corrosion product in the sterile solution or the corrosion product and biofilm in Desulfovibrio caledoniensis media, while the other one at low-frequency was associated with the electrical double layer (Guan et al., 2017). So the two time constants at high frequency and low frequency were related to $R_{p}$ and $\mathrm{R}_{\mathrm{ct}}$, respectively.

In sterile seawater, the impedance loop diameter, the $R_{c t}$ value, and the $R_{p}$ value increased from 1 to 30 day exposure. Nevertheless, the average corrosion rate and the $\mathrm{I}_{\text {corr }}$ value decreased from 3 to 30 day exposure and from 1 to 30 day exposure, respectively. These changes illustrated that the corrosion rate of the steel exposed in sterile seawater decreased from 1 to 30 day exposure. These results could be due to the increase of the amount of the corrosion products on the coupon, which could decrease the transmission of corrosive ions and molecules to the steel surface (Li S. et al., 2016). Similarly, the resistance of the corrosion products film formed on AISI 304 stainless steel increased in the first 10 days of immersion in sterile seawater due to the increase in thickness of the corrosion products (Rodríguez et al., 2006). The corrosion product increased the impedance value of AZ31B magnesium alloy immersed in the artificial seawater (Kang et al., 2019). The increase of the $R_{c t}$ value of the naval carbon steel BV-grade A in natural seawater was due to the increase in the thickness and/or compactness of the corrosion products layer (Belkaid et al., 2011). The pit number, the maximum pit depth, and the corresponding width results in sterile seawater showed the pitting corrosion of the steel exposed in sterile seawater, which could be attributed to the concentration cells caused by the heterogeneous corrosion products film (Fadl-allah et al., 2016).

The EIS data showed that the impedances including the impedance loop diameters, the $R_{c t}$ values, and the $R_{p}$ values in Flavobacterium sp. inoculated seawater considerably increased after $1,3,5,7$, and 30 day exposure and considerably decreased after 15 and 21 day exposure as compared to their counterparts in sterile seawater, which were in accord with the $\mathrm{I}_{\text {corr }}$ results of the polarization curves and the weight loss data. These results demonstrated that Flavobacterium sp. decreased the corrosion rates of the steel between 1 and 7 day exposure and after 30 day exposure and increased the corrosion rates between 15 and 21 day exposure. The FM and the SEM results revealed that Flavobacterium sp. formed the biofilm on the coupons. The biofilm acted as a transport barrier, blocking the diffusion of the corrosive species such as oxygen and chloridion to the steel surface (Mohanan et al., 2004; Guo et al., 2017). Even it could prevent the diffusion of the corrosion products $(\mathrm{Qu}$ et al., 2015). Besides, the biofilm could remove oxygen at the steel/electrolyte interface through oxygen respiration (Little and Ray, 2002). These led to the increases in the impedances and decreases in the $I_{\text {corr }}$ values, the average corrosion rates, and the corrosion rates. Thus, the decreases of the corrosion rates by Flavobacterium sp. could be attributed to the corrosion inhibition by the biofilm, which were supported by previous studies. Bacillus subtilis increased the impedance value and decreased the corrosion rate due to the formation of the biofilm on the AZ31B magnesium alloy surface (Kang et al., 2019). The $P$. aeruginosa biofilm increased the $\mathrm{R}_{\mathrm{ct}}$ values of nickel-zinc alloys, suggesting that this species inhibited corrosion on nickelzinc surfaces (San et al., 2014). D. desulfuricans increased the $\mathrm{R}_{\mathrm{ct}}$ value of carbon steel Q235 and decreased the corrosion rate, which was attributed to the protective ability of the biofilm (Sun et al., 2011). However, the cell count data and the $\mathrm{pH}$ results showed that in Flavobacterium sp. inoculated seawater, the cell number variations with exposure time were contrary to the $\mathrm{pH}$ value profiles, indicating that the acid secreted by Flavobacterium sp. was correlated to the stages of the cell proliferation, that is the amount of the secreted acid increased with the cell number increase and decreased with the cell number decrease due to nutrient starvation. These results were consistent with the profiles of the organic acid secretion by $B$. subtilis, in which the organic acid secreted by $B$. subtilis is associated with the reproduction of the microorganism ( $\mathrm{Qu}$ et al., 2015). Importantly, the $\mathrm{pH}$ values in Flavobacterium sp. inoculated seawater considerably decreased relative to the corresponding ones in sterile seawater after 15 and 21 day exposure and reached the acidic values about 5.6 and 6.2. Acting as the depolarizer, the acid secreted by Flavobacterium sp. increased the cathodic depolarization, i.e., hydrogen evolution reaction, and decreased the deposition of the corrosion products on the steel surface through decreasing the concentration of hydroxyl radical. These caused the decreases in the impedances and increases in the $\mathrm{I}_{\text {corr }}$ values, the average corrosion rates, and the corrosion rates. So the increases of the corrosion rates by Flavobacterium sp. could be attributed to the corrosion acceleration by the acid from Flavobacterium sp., which were supported by the following results. The acetate produced by $D$. desulfuricans decreased the environmental $\mathrm{pH}$ and increased the corrosion rate of the iron (Pak et al., 2003). The organic acids such as lactic acid, fumaric acid, malic acid, and linoleic acid produced by Trichoderma harzianum decreased the $R_{c t}$ value and the $R_{p}$ value of $A Z 31 B$ magnesium alloy in artificial seawater and increased the corrosion rate $(\mathrm{Qu}$ et al., 2017). The low $\mathrm{pH}$ attributed to the acid produced by the ironoxidizing bacteria enhanced the corrosion rate of the petrol tank (Manga et al., 2012).

The surface analysis results showed that the pit numbers, the maximum pit depths, and the corresponding widths in Flavobacterium sp. inoculated seawater considerably increased as compared to their counterparts in sterile seawater. The polarization curves results showed that the $\mathrm{E}_{\mathrm{pit}}$ values in Flavobacterium sp. inoculated seawater considerably decreased as compared to their counterparts in sterile seawater. These results demonstrated that Flavobacterium sp. increased the pitting corrosion of the steel. Moreover, the FM results showed that the coverage and the heterogeneity of the biofilm increased with exposure time. The increases in the maximum pit depth and the corresponding width and the decrease in the $\mathrm{E}_{\mathrm{pit}}$ 
value by Flavobacterium sp. exhibited the similar trends to the two formers. The bacterial accumulation depended on the communication of the bacteria through the released quorum sensing signal molecules (Fuqua et al., 1994; Hamzah et al., 2013). In turn, the signal molecules were assembled by the accumulating bacteria (Waters and Bassler, 2005). As time went on, the biofilm became more massive (Bollinger et al., 2001). More importantly, the biofilm became more heterogeneous (Hentzer and Givskov, 2003). The aggressive ions and molecules diffused more difficultly to the steel surface areas coated by the biofilm than to the uncoated areas, which formed the concentration cells. Furthermore, the oxygen consumption by the biofilm aggravated the differences in oxygen concentration between the coated and the uncoated areas. The higher the coverage and the heterogeneity of the biofilm the greater the concentration differences of the corrosive substances between the coated and the uncoated areas, which served as the anodes and the cathodes of the concentration cells, respectively (Zarasvand and Rai, 2014). The anodic dissolution led to the pitting corrosion. So the pitting corrosion by Flavobacterium sp. could be attributed to the heterogeneous biofilm cover. Similarly, the increases in thickness and heterogeneity of the $P$. aeruginosa biofilm caused the more severe pitting corrosion of mild steel (Abdolahi et al., 2015). The increases of the Desulfovibrio alaskensis biofilm porosity and heterogeneity led to the increases of the pitting corrosion of St372 (S235-JR) carbon steel (Wikieł et al., 2014). The heterogeneous biofilm of M11 and S8-5 SRB resulted in the gradients of $\mathrm{pH}$, sulfate, and chloride and the pitting corrosion of mild steel (Xu et al., 2002).

\section{CONCLUSION}

In this study, AISI 1045 steel corrosion by Flavobacterium sp. was explored by weight loss, FM, surface analysis, cell count, $\mathrm{pH}$ measure, EIS, and polarization curves. Flavobacterium sp. considerably increased the impedances after 1, 3, 5, 7, and 30 day exposure and considerably decreased the impedances after 15 and 21 day exposure, which were in agreement with the $\mathrm{I}_{\text {corr }}$ results and the weight loss data. Additionally, the Flavobacterium sp.

\section{REFERENCES}

Abdolahi, A., Hamzah, E., Ibrahim, Z., and Hashim, S. (2015). Localised corrosion of mild steel in presence of Pseudomonas aeruginosa biofilm. Corros. Eng. Sci. Technol. 50, 538-546. doi: 10.1179/1743278215Y.0000000003

Abell, G. C. J., and Bowman, J. P. (2005). Ecological and biogeographic relationships of class Flavobacteria in the Southern Ocean. FEMS Microbiol. Ecol. 51, 265-277. doi: 10.1016/j.femsec.2004.09.001

Batmanghelich, F., Li, L., and Seo, Y. (2017). Influence of multispecies biofilms of Pseudomonas aeruginosa and Desulfovibrio vulgaris on the corrosion of cast iron. Corros. Sci. 121, 94-104. doi: 10.1016/j.corsci.2017.03.008

Belkaid, S., Ladjouzi, M. A., and Hamdani, S. (2011). Effect of biofilm on naval steel corrosion in natural seawater. J. Solid State Electrochem. 15, 525-537. doi: 10.1007/s10008-010-1118-5

Bhandari, J., Khan, F., Abbassi, R., Garaniya, V., and Ojeda, R. (2015). Modelling of pitting corrosion in marine and offshore steel structures-A technical review. J. Loss Prev. Process Ind. 37, 39-62. doi: 10.1016/j.jlp.2015. 06.008 biofilm formed on the coupons. Flavobacterium sp. considerably decreased the $\mathrm{pH}$ values after 15 and 21 day exposure. These results demonstrated that Flavobacterium sp. decreased the corrosion rates between 1 and 7 day exposure and after 30 day exposure and increased the corrosion rates between 15 and 21 day exposure, which was associated with the corrosion inhibition by the biofilm and the corrosion acceleration by the secreted acid, respectively. In addition, Flavobacterium sp. considerably increased the pit numbers, the maximum pit depths, and the corresponding widths and considerably decreased the $\mathrm{E}_{\text {pit }}$ values. Importantly, together with the increases in the maximum pit depth and the corresponding width and the decrease in the $\mathrm{E}_{\mathrm{pit}}$ value by Flavobacterium sp., the coverage and the heterogeneity of the biofilm increased with exposure time. The results demonstrated that Flavobacterium sp. increased the pitting corrosion, which could be attributed to the heterogeneous biofilm cover.

\section{DATA AVAILABILITY STATEMENT}

All datasets generated for this study are included in the article/supplementary material.

\section{AUTHOR CONTRIBUTIONS}

JW and WZ performed the experiments. JW, WZ, and KC analyzed the data, and wrote the manuscript. JW and KC designed the experiments and modified the manuscript. AY modified the manuscript.

\section{FUNDING}

This work was supported by the Hainan Provincial Natural Science Foundation of China (No. 517064), National Natural Science Foundation of China (Nos. 51761011, 51261006, 51161007, and 50761004), and the China Scholarship Council (No. 201808460075).

Bollinger, N., Hassett, D. J., Iglewski, B. H., Costerton, J. W., and McDermott, T. R. (2001). Gene expression in Pseudomonas aeruginosa: evidence of iron override effects on quorum sensing and biofilm-specific gene regulation. J. Bacteriol. 183, 1990-1996. doi: 10.1128/JB.183.6.1990-1996.2001

Castaneda, H., and Benetton, X. D. (2008). SRB-biofilm influence in active corrosion sites formed at the steel-electrolyte interface when exposed to artificial seawater conditions. Corros. Sci. 50, 1169-1183. doi: 10.1016/j.corsci. 2007.11.032

Chen, S., Liu, G., and Zhang, D. (2019). Corrosion of Q235 carbon steel in seawater containing Mariprofundus ferrooxydans and Thalassospira sp. Front. Microbiol. 10:936. doi: 10.3389/fmicb.2019.00936

Chen, Y., Tang, Q., Senko, J., Cheng, G., Newby, B. M. Z., Castaneda, H., et al. (2015). Long-term survival of Desulfovibrio vulgaris on carbon steel and associated pitting corrosion. Corros. Sci. 90, 89-100. doi: 10.1016/j.corsci.2014. 09.016

Cook, D. C. (2005). Spectroscopic identification of protective and non-protective corrosion coatings on steel structures in marine environments. Corros. Sci. 47, 2550-2570. doi: 10.1016/j.corsci.2004.10.018 
Dong, Y., Lekbach, Y., Li, Z., Xu, D., Abed, S. E., Koraichi, S. I., et al. (2020). Microbiologically influenced corrosion of 304L stainless steel caused by an alga associated bacterium Halomonas titanicae. J. Mater. Sci. Technol. 37, 200-206. doi: 10.1016/j.jmst.2019.06.023

Dou, W., Jia, R., Jin, P., Liu, J., Chen, S., and Gu, T. (2018). Investigation of the mechanism and characteristics of copper corrosion by sulfate reducing bacteria. Corros. Sci. 144, 237-248. doi: 10.1016/j.corsci.2018.08.055

Fadl-allah, S. A., Montaser, A. A., and El-Rab, S. M. G. (2016). Biocorrosion control of electroless Ni-Zn-P coating based on carbon steel by the pseudomonas aeruginosa biofilm. Int. J. Electrochem. Sci. 11, 5490-5506. doi: 10.20964/2016. 07.96

Fuqua, W. C., Winans, S. C., and Greenberg, E. P. (1994). Quorum sensing in bacteria: the LuxR-LuxI family of cell density-responsive transcriptional regulators. J. Bacteriol. 176, 269-275. doi: 10.1128/jb.176.2.269-275.1994

Ghiara, G., Spotorno, R., Trasatti, S. P., and Cristiani, P. (2018). Effect of Pseudomonas fluorescens on the electrochemical behaviour of a single-phase Cu-Sn modern bronze. Corros. Sci. 139, 227-234. doi: 10.1016/j.corsci.2018. 05.009

Gu, T., Jia, R., Unsal, T., and Xu, D. (2019). Toward a better understanding of microbiologically influenced corrosion caused by sulfate reducing bacteria. J. Mater. Sci. Technol. 35, 631-636. doi: 10.1016/j.jmst.2018.10.026

Guan, F., Zhai, X., Duan, J., Zhang, J., Li, K., and Hou, B. (2017). Influence of sulfate-reducing bacteria on the corrosion behavior of 5052 aluminum alloy. Surf. Coat. Technol. 316, 171-179. doi: 10.1016/j.surfcoat.2017.02.057

Guan, J., Xia, L. P., Wang, L. Y., Liu, J. F., Gu, J. D., and Mu, B. Z. (2013). Diversity and distribution of sulfate-reducing bacteria in four petroleum reservoirs detected by using $16 \mathrm{~S}$ rRNA and dsrAB genes. Int. Biodeterior. Biodegrad. 76, 58-66. doi: 10.1016/j.ibiod.2012.06.021

Guo, Z., Liu, T., Cheng, Y. F., Guo, N., and Yin, Y. (2017). Adhesion of Bacillus subtilis and Pseudoalteromonas lipolytica to steel in a seawater environment and their effects on corrosion. Colloids Surf. B 157, 157-165. doi: 10.1016/j.colsurfb. 2017.05.045

Hamzah, E., Hussain, M. Z., Ibrahim, Z., and Abdolahi, A. (2013). Influence of Pseudomonas aeruginosa bacteria on corrosion resistance of 304 stainless steel. Corros. Eng. Sci. Technol. 48, 116-120. doi: 10.1179/1743278212Y.0000000052

Hentzer, M., and Givskov, M. (2003). Pharmacological inhibition of quorum sensing for the treatment of chronic bacterial infections. J. Clin. Invest. 112, 1300-1307. doi: 10.1172/JCI20074

Hernandez, G., Kucera, V., Thierry, D., Pedersen, A., and Hermansson, M. (1994). Corrosion inhibition of steel by bacteria. Corrosion 50, 603-608. doi: 10.5006/1. 3293532

Hu, Y., Xiao, K., Zhang, D., Yi, P., Xiong, R., Dong, C., et al. (2019). Corrosion acceleration of printed circuit boards with an immersion silver layer exposed to Bacillus cereus in an aerobic medium. Front. Microbiol. 10:1493. doi: 10.3389/ fmicb.2019.01493

Ilhan-Sungur, E., and Çotuk, A. (2010). Microbial corrosion of galvanized steel in a simulated recirculating cooling tower system. Corros. Sci. 52, 161-171. doi: 10.1016/j.corsci.2009.08.049

Jayaraman, A., Ornek, D., Duarte, D. A., Lee, C. C., Mansfeld, F. B., and Wood, T. K. (1999). Axenic aerobic biofilms inhibit corrosion of copper and aluminum. Appl. Microbiol. Biotechnol. 52, 787-790. doi: 10.1007/s00253005159

Jin, Y., Li, Z., Zhou, E., Lekbach, Y., Xu, D., Jiang, S., et al. (2019). Sharing riboflavin as an electron shuttle enhances the corrosivity of a mixed consortium of Shewanella oneidensis and Bacillus licheniformis against 316L stainless steel. Electrochim. Acta 316, 93-104. doi: 10.1016/j.electacta.2019.05.094

Kang, Y., Li, L., Li, S., Zhou, X., Xia, K., Liu, C., et al. (2019). Temporary inhibition of the corrosion of AZ31B magnesium alloy by formation of Bacillus subtilis biofilm in artificial seawater. Materials 12:523. doi: 10.3390/ma12030523

Li, H., Yang, C., Zhou, E., Yang, C., Feng, H., Jiang, Z., et al. (2017). Microbiologically influenced corrosion behavior of S32654 super austenitic stainless steel in the presence of marine Pseudomonas aeruginosa biofilm. J. Mater. Sci. Technol. 33, 1596-1603. doi: 10.1016/j.jmst.2017.03.002

Li, H., Zhou, E., Ren, Y., Zhang, D., Xu, D., Yang, C., et al. (2016). Investigation of microbiologically influenced corrosion of high nitrogen nickel-free stainless steel by Pseudomonas aeruginosa. Corros. Sci. 111, 811-821. doi: 10.1016/j. corsci.2016.06.017

Li, S., Bacco, A. C., Birbilis, N., and Cong, H. (2016). Passivation and potential fluctuation of $\mathrm{Mg}$ alloy AZ31B in alkaline environments. Corros. Sci. 112, 596-610. doi: 10.1016/j.corsci.2016.08.022
Li, X., Duan, J., Xiao, H., Li, Y., Liu, H., Guan, F., et al. (2017). Analysis of bacterial community composition of corroded steel immersed in Sanya and Xiamen seawaters in China via method of illumina MiSeq sequencing. Front. Microbiol. 8:1737. doi: 10.3389/fmicb.2017.01737

Li, Y., Jia, R., Al-Mahamedh, H. H., Xu, D., and Gu, T. (2016). Enhanced biocide mitigation of field biofilm consortia by a mixture of D-amino acids. Front. Microbiol. 7:896. doi: 10.3389/fmicb.2016.00896

Li, Y., Xu, D., Chen, C., Li, X., Jia, R., Zhang, D., et al. (2018). Anaerobic microbiologically influenced corrosion mechanisms interpreted using bioenergetics and bioelectrochemistry: a review. J. Mater. Sci. Technol. 34, 1713-1718. doi: 10.1016/j.jmst.2018.02.023

Little, B., and Ray, R. (2002). A perspective on corrosion inhibition by biofilms. Corrosion 58, 424-428. doi: 10.5006/1.3277632

Liu, F., Zhang, J., Sun, C., Yu, Z., and Hou, B. (2014). The corrosion of two aluminium sacrificial anode alloys in SRB-containing sea mud. Corros. Sci. 83, 375-381. doi: 10.1016/j.corsci.2014.03.003

Liu, H., Fu, C., Gu, T., Zhang, G., Lv, Y., Wang, H., et al. (2015). Corrosion behavior of carbon steel in the presence of sulfate reducing bacteria and iron oxidizing bacteria cultured in oilfield produced water. Corros. Sci. 100, 484-495. doi: 10.1016/j.corsci.2015.08.023

Liu, H., Gu, T., Asif, M., Zhang, G., and Liu, H. (2017). The corrosion behavior and mechanism of carbon steel induced by extracellular polymeric substances of iron-oxidizing bacteria. Corros. Sci. 114, 102-111. doi: 10.1016/j.corsci.2016. 10.025

Liu, H., Meng, G., Li, W., Gu, T., and Liu, H. (2019). Microbiologically influenced corrosion of carbon steel beneath a deposit in CO2-saturated formation water containing Desulfotomaculum nigrificans. Front. Microbiol. 10:1298. doi: 10. 3389/fmicb.2019.01298

Liu, J. C., Park, S., Nagao, S., Nogi, M., Koga, H., Ma, J. S., et al. (2015). The role of $\mathrm{Zn}$ precipitates and $\mathrm{Cl}$ - anions in pitting corrosion of $\mathrm{Sn}-\mathrm{Zn}$ solder alloys. Corros. Sci. 92, 263-271. doi: 10.1016/j.corsci.2014.12.014

Manga, S. S., Oyeleke, S. B., Ibrahim, A. D., Aliero, A. A., and Bagudo, A. I. (2012). Influence of bacteria associated with corrosion of metals. CJMB 6, 19-25.

Mansfeld, F., and Little, B. (1991). A technical review of electrochemical techniques applied to microbiologically influenced corrosion. Corros. Sci. 32, 247-272. doi: 10.1016/0010-938X(91)90072-W

Melchers, R. E., and Jeffrey, R. (2008). Modeling of long-term corrosion loss and pitting for chromium-bearing and stainless steels in seawater. Corrosion 64, 143-154. doi: 10.5006/1.3280683

Mohanan, S., Maruthamuthu, S., Venkatachari, G., Palaniswamy, N., and Raghavan, M. (2004). Corrosion inhibition by freshwater biofilm on 316 stainless steel. Bull. Electrochem. 20, 129-132. doi: 10.1016/j.jpowsour.2003. 09.031

OrjuelaG, A., Rincón, R., and Olaya, J. J. (2014). Corrosion resistance of niobium carbide coatings produced on AISI 1045 steel via thermo-reactive diffusion deposition. Surf. Coat. Technol. 259, 667-675. doi: 10.1016/j.surfcoat.2014. 10.012

Page, C. L. (1975). Mechanism of corrosion protection in reinforced concrete marine structures. Nature 258, 514-515. doi: 10.1038/258514a0

Pak, K. R., Lee, H. J., Lee, H. K., Kim, Y. K., Oh, Y. S., and Choi, S. C. (2003). Involvement of organic acid during corrosion of iron coupon by Desulfovibrio desulfuricans. J. Microbiol. Biotechnol. 13, 937-941.

Pérez, E. J., Cabrera-Sierra, R., González, I., and Ramírez-Vives, F. (2007). Influence of Desulfovibrio sp. biofilm on SAE 1018 carbon steel corrosion in synthetic marine medium. Corros. Sci. 49, 3580-3597. doi: 10.1016/j.corsci.2007. 03.034

Pesciaroli, C., Cupini, F., Selbmann, L., Barghini, P., and Fenice, M. (2012). Temperature preferences of bacteria isolated from seawater collected in Kandalaksha Bay, White Sea, Russia. Polar Biol. 35, 435-445. doi: 10.1007/ s00300-011-1091-1

Popoola, L. T., Grema, A. S., Latinwo, G. K., Gutti, B., and Balogun, A. S. (2013). Corrosion problems during oil and gas production and its mitigation. Int. J. Ind. Chem. 4:35. doi: 10.1186/2228-5547-4-35

Qu, Q., He, Y., Wang, L., Xu, H., Li, L., Chen, Y., et al. (2015). Corrosion behavior of cold rolled steel in artificial seawater in the presence of Bacillus subtilis C2. Corros. Sci. 91, 321-329. doi: 10.1016/j.corsci.2014.11.032

Qu, Q., Li, S., Li, L., Zuo, L., Ran, X., Qu, Y., et al. (2017). Adsorption and corrosion behaviour of Trichoderma harzianum for AZ31B magnesium alloy in artificial seawater. Corros. Sci. 118, 12-23. doi: 10.1016/j.corsci.2017.01.005 
Ringas, C., and Robinson, F. P. A. (1988). Corrosion of stainless steel by sulfatereducing bacteria-electrochemical techniques. Corrosion 44, 386-396. doi: 10. 5006/1.3583953

Rodríguez, J. S., Hernández, F. S., and González, J. G. (2006). Comparative study of the behaviour of AISI 304 SS in a natural seawater hopper, in sterile media and with SRB using electrochemical techniques and SEM. Corros. Sci. 48, 1265-1278. doi: 10.1016/j.corsci.2005.04.007

San, N. O., Nazır, H., and Dönmez, G. (2014). Microbially influenced corrosion and inhibition of nickel-zinc and nickel-copper coatings by Pseudomonas aeruginosa. Corros. Sci. 79, 177-183. doi: 10.1016/j.corsci.2013.11.004

Song, W., Chen, X., He, C., Li, X., and Liu, C. (2018). Microbial corrosion of 2205 duplex stainless steel in oilfield-produced water. Int. J. Electrochem. Sci. 13, 675-689. doi: 10.20964/2018.01.54

Starosvetsky, D., Armon, R., Yahalom, J., and Starosvetsky, J. (2001). Pitting corrosion of carbon steel caused by iron bacteria. Int. Biodeterior. Biodegrad. 47, 79-87. doi: 10.1016/S0964-8305(99)00081-5

Sun, C., Xu, J., and Wang, F. (2011). Interaction of sulfate-reducing bacteria and carbon steel Q 235 in biofilm. Ind. Eng. Chem. Res. 50, 12797-12806. doi: 10.1021/ie200952y

Voordouw, G., Menon, P., Pinnock, T., Sharma, M., Shen, Y., Venturelli, A., et al. (2016). Use of homogeneously-sized carbon steel ball bearings to study microbially-influenced corrosion in oil field samples. Front. Microbiol. 7:351. doi: $10.3389 /$ fmicb. 2016.00351

Wang, H., Ju, L. K., Castaneda, H., Cheng, G., and Newby, B. M. Z. (2014). Corrosion of carbon steel C1010 in the presence of iron oxidizing bacteria Acidithiobacillus ferrooxidans. Corros. Sci. 89, 250-257. doi: 10.1016/j.corsci. 2014.09.005

Wang, Z., Gao, J., Ai, T., Jiang, W., and Zhao, P. (2014). Quantitative evaluation of carbon fiber dispersion in cement based composites. Constr. Build. Mater. 68, 26-30. doi: 10.1016/j.conbuildmat.2014.06.035

Waters, C. M., and Bassler, B. L. (2005). Quorum sensing: cell-to-cell communication in bacteria. Annu. Rev. Cell Dev. Biol. 21, 319-346. doi: 10. 1146/annurev.cellbio.21.012704.131001

Wikieł, A. J., Datsenko, I., Vera, M., and Sand, W. (2014). Impact of Desulfovibrio alaskensis biofilms on corrosion behaviour of carbon steel in marine environment. Bioelectrochemistry 97, 52-60. doi: 10.1016/j.bioelechem. 2013.09.008

Wu, J. Y., Xiao, W. L., Yang, Y. H., Cao, Y., and Chai, K. (2012). Influence of Pseudomonas on corrosion and mechanical properties of carbon steel in sea water. Corros. Eng. Sci. Technol. 47, 91-95. doi: 10.1179/1743278211y. 0000000031
Xiao, W. L. (2011). Effect of Microbial Corrosion Process on the Mechanical Properties of Carbon Steel in Tropical Seawater Condition. Master's thesis, Hainan University, Haikou.

Xu, D., Xia, J., Zhou, E., Zhang, D., Li, H., Yang, C., et al. (2017). Accelerated corrosion of 2205 duplex stainless steel caused by marine aerobic Pseudomonas aeruginosa biofilm. Bioelectrochemistry 113, 1-8. doi: 10.1016/j.bioelechem. 2016.08.001

Xu, J., Sun, C., Yan, M., and Wang, F. (2012). Effects of sulfate reducing bacteria on corrosion of carbon steel Q235 in soil-extract solution. Int. J. Electrochem. Sci. 7, 11281-11296.

Xu, L. C., Chan, K. Y., and Fang, H. H. (2002). Application of atomic force microscopy in the study of microbiologically influenced corrosion. Mater. Charact. 48, 195-203. doi: 10.1016/S1044-5803(02) 00239-5

Yuan, S. J., Pehkonen, S. O., Ting, Y. P., Kang, E. T., and Neoh, K. G. (2008). Corrosion behavior of type 304 stainless steel in a simulated seawaterbased medium in the presence and absence of aerobic Pseudomonas NCIMB 2021 bacteria. Ind. Eng. Chem. Res. 47, 3008-3020. doi: 10.1021/ie071 $536 \mathrm{x}$

Zarasvand, K. A., and Rai, V. R. (2014). Microorganisms: induction and inhibition of corrosion in metals. Int. Biodeterior. Biodegrad. 87, 66-74. doi: 10.1016/j. ibiod.2013.10.023

Zhao, Y., Zhou, E., Liu, Y., Liao, S., Li, Z., Xu, D., et al. (2017). Comparison of different electrochemical techniques for continuous monitoring of the microbiologically influenced corrosion of 2205 duplex stainless steel by marine Pseudomonas aeruginosa biofilm. Corros. Sci. 126, 142-151. doi: 10.1016/j. corsci.2017.06.024

Zhou, E., Li, H., Yang, C., Wang, J., Xu, D., Zhang, D., et al. (2018). Accelerated corrosion of 2304 duplex stainless steel by marine Pseudomonas aeruginosa biofilm. Int. Biodeterior. Biodegrad. 127, 1-9. doi: 10.1016/j.ibiod.2017.11.003

Conflict of Interest: The authors declare that the research was conducted in the absence of any commercial or financial relationships that could be construed as a potential conflict of interest.

Copyright (c) $2020 \mathrm{Wu}$, Zhang, Chai and Yu. This is an open-access article distributed under the terms of the Creative Commons Attribution License (CC BY). The use, distribution or reproduction in other forums is permitted, provided the original author(s) and the copyright owner(s) are credited and that the original publication in this journal is cited, in accordance with accepted academic practice. No use, distribution or reproduction is permitted which does not comply with these terms. 